\author{
О.В. Турінський, Б.О. Демідов, Д.А. Гриб, О.О. Хмелевська
}

Харківський національний університет Повітряних Сил ім. І. Кожедуба, Харків

\title{
НАУКОВО-МЕТОДОЛОГІЧНІ АСПЕКТИ УПРАВЛІННЯ РИЗИКАМИ У СИСТЕМІ ДЕРЖАВНОГО ОБОРОННОГО ЗАМОВЛЕННЯ
}

У статті розглядаються актуальні аспекти, щчо пов'язані з прочедурами формування і реалізації державних оборонних замовлень в умовах прояву різних факторів ризику. Основна увага зосереджена на науково-методичному підході до очінювання рівня очікуваних ризиків і управління цими ризиками. Відмічається, щз використання при формуванні і реалізачії державного оборонного замовлення відповідних адекватних методів, моделей $і$ методик буде сприяти зменшенню рівня ризику і підвищенню результативності виконання завдань $і$ заходів державного оборонного замовлення. Доведено, про доцільність врахування у вітчизняній практиці накопиченого позитивного досвіду провідних країн світу із зменшення ризиків невиконання наукових і інших перспективних (інноваційних) проектів створення зразків озброєння $і$ військової техніки, які мають складати основу системи озброєння збройних сил держави. Під ризиком у статті розуміється міра нездатності досягнення мети програми у рамках запланованої вартості, термінів робіт і технічних вимог, щуо надає ризику складових імовірності недосяжності конкретної мети програми і наслідків недосяжності даної мети. За досвідом МО США виділяються аспекти прийняття ризику, ухилення від ризику, контролю ризику, передачі ризику і комбінаџії вищевказаних способів для реагування на подію ризику. Виділяється найбільш важливий метод оцінювання факторів ризику у системі державного оборонного замовлення, щзо зорієнтований на встановлення величини втрат економічного характеру. Приводиться актуальність проблеми управління ризиками у проиесі виконання заходів державного оборонного замовлення $і$ державних цільових програм розвитку озброєння і військової техніки в умовах збільшення невизначеності і все більшого розширення масштабів прояву факторів ризику. Виокремлена необхідність створення дієвого бережливого механізму господарювання оборонно-промислового комплексу держави в умовах прояву різних факторів ризику на усьому періоді життєвого ичилу системи озброєння збройних сил.

Ключові слова: державне оборонне замовлення, фактори ризиків у системі державного оборонного замовлення, методи оцінювання рівня прояву факторів ризику, методи управління ризиками.

\section{Вступ}

Постановка проблеми. Забезпечення безпеки i захисту національних інтересів неможливе без вирішення задач технічного оснащення збройних сил (3C) новітніми системи озброєння у відповідності 3 призначенням і задачами видів (складових) 3С, формами і способами їх застосування, економічними i мобілізаційними можливостями держави [1-3].

Якісна модернізація 3С у першу чергу залежить від ступеню охоплення потреб ЗС, послідовністю і реалізацією державної цільової програми розвитку (ДЦПР) озброєння і військової техніки (ОВТ) та стабільністю державних оборонних замовлень (ДОЗ) на довгостроковому періоді планування розвитку 3С. Державне оборонне замовлення є одним 3 основних інструментів управління обороною сферою і впливає на створення як системи озброєння 3С, так і розвиток підприємств оборонно-промислового комплексу (ОПК).

Механізм формування, розміщення і реалізації цього замовлення функціонує у складних умовах, що характеризуються високими ризиками невизначеності і наявністю факторів ризику різного харак- теру, тому проблема управління ризиками у системі ДОЗ в умовах невизначеності і все більшого прояву факторів ризику стає вельми актуальною [4-5; 9].

Вирішення вказаної проблеми може бути подане у вигляді наступної сукупності задач:

- обгрунтування ролі і змісту напрямку розвитку контрактного механізму реалізації ДО3;

- виявлення сукупності проблем і протиріч функціонування системи ДОЗ (СДОЗ) в умовах наявного потенціалу оборонно-промислового комплексу (ОПК) і його змін на періоді середньострокового і довгострокового планування, а також визначення напрямків їх вирішення;

- систематизація і розробка класифікаційної моделі ризиків на макро-, мезо- і мікрорівнях у системі ДОЗ на період реалізації ДЦПР;

- розробка комплексу методик оцінювання ризиків у процесі створення зразків ОВТ і реалізації ДОЗ;

- обгрунтування і розробка методів управління ризиками у системі державних оборонних замовлень.

Наявність науково-методологічного апарату управління ризиками (НМАУР) є вирішальною умо- 
вою підвищення ефективності функціонування системи ДОЗ. Основи цього апарату мають відбивати загальноекономічні, управлінські і організаційні аспекти і складатись з базових теоретичних установок, механізмів, методів і критеріїв оцінювання ефективності управління ризиками. У теперішній час існує невідкладна потреба у створенні єдиної концептуальної моделі управління ризиками у державних оборонних замовленнях.

\section{Стан теорії і практики управління ризиками у воєнно-технічній області}

Оцінюванню ризиків і управління ними у ході реалізації програми придбання ОВТ у провідних країнах світу приділяється значна увага [6-7]. У США ще у 1969 неадекватність вирішення даної проблеми була названа міністерством оборони (МO) у числі основних причин недостатньої ефективності функціонування системи воєнних науково-дослідних конструкторських робіт (НДКР). Пізніше конгрес вимагав від МО США більш чіткого визначення ризиків створення зразків ОВТ при формуванні бюджетних замовлень на фінансування НДКР.

У Великій Британії підвищена увага до питань оцінювання і управління ризиком розробки і виробництва ОВТ стала приділятися починаючи 3 80-х років минулого сторіччя. У цілях підвищення ефективності управління ризиками для крупних програм придбання ОВТ у склад робочої групи керівників стала залучатись група спеціалістів, що відповідала за управління ризиками на усіх стадіях життєвого циклу (ЖЦ) ОВТ. Основною метою діяльності спеціалістів по ризикам стало не просто визначення наявності і рівнів ризиків, а і відпрацювання заходів 3 їх зниження. У американських джерелах, що стосуються питань аналізу і управління ризиками, використовуються різні терміни, що визначають ці процеси або його елементи. У керівних документах MO CША (DOD 5000.1 і DOD 5000.2) використову- ються наступні терміни для складових елементів етапів процесу управління ризиком (risk management):

- планування ризику (risk planning);

- оцінювання ризику (risk assessment);

- аналіз ризику (risk analysis);

- зниження ризику (risk reduction).

Крім того, у елементі “оцінювання ризику” іноді виділяють піделемент ідентифікації ризику (risk identification), а у елементі зниження ризику піделемент “подолання наслідків реалізації події ризику" (risk handling).

У керівництві МО США з управління ризиком (risk management Guide) під ризиком розуміється міра нездатності досягнення мети програми придбання ОВТ у рамках запланованої вартості, термінів робіт і технічних вимог, що мають дві складові частини: імовірність недосяжності конкретної мети програми; наслідки недосягнення даної мети.

Для процесу придбання ризик - це міра відхилення ходу реального процесу від відомих найкращих випадків його організації. В основі ефективного управління ризиком лежить чітке представлення про те, де знаходиться даний ризик у координатах, імовірність події і масштаб наслідків, що дає можливість оптимізувати з урахуванням наявних ресурсів комбінацію заходів з управління ризиком.

Методи, що зорієнтовані на оцінювання ризику перевищення вартості програми, визнаються американськими спеціалістами найважливішими серед методів аналізу ризиків, у кінцевому випадку ці наслідки реалізації випадків ризику можуть бути виражені у грошовій формі. У цілому документи МО США передбачають управління ризиками на всіх етапах виконання програми придбання ОВТ і розглядають його як безперервний багатоітераційний процес (рис. 1).

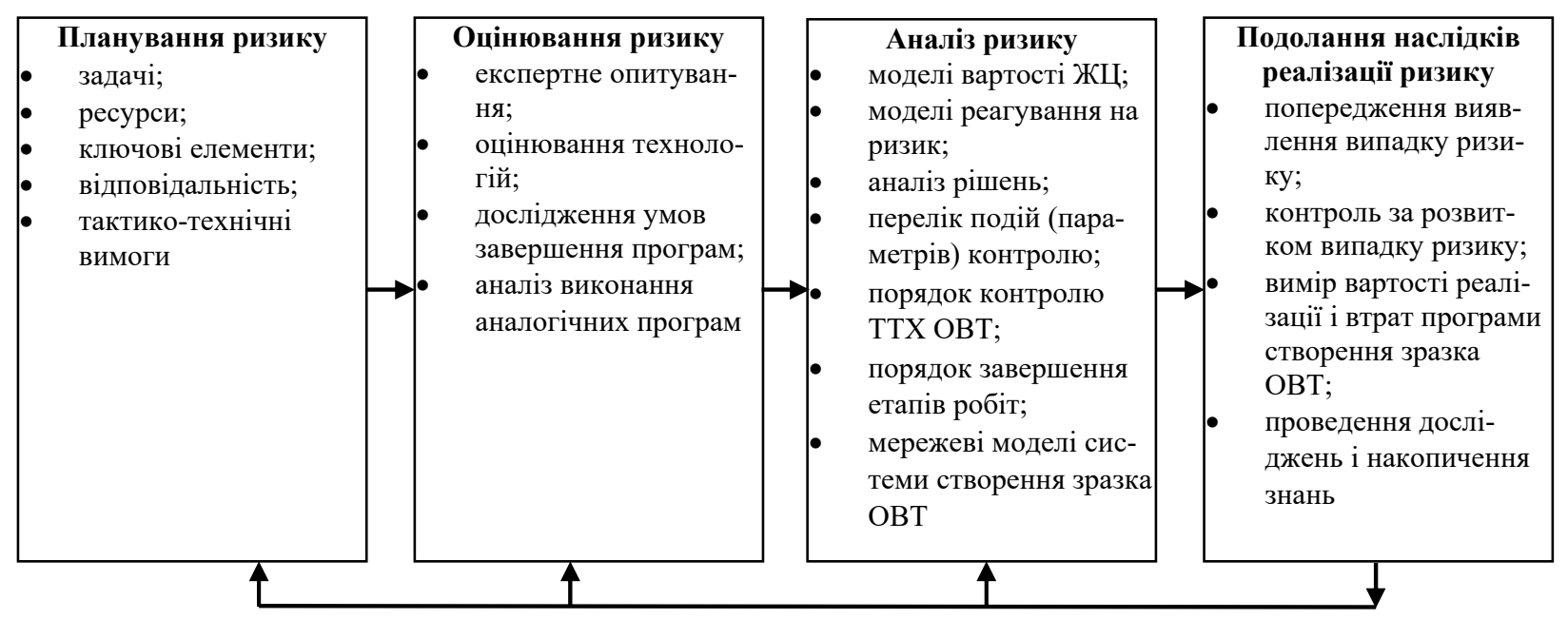

Рис. 1. Взаємозв’язок елементів процесу управління ризиком (згідно DOD 5000.2) 
У залежності від фази програми і складності проблем, що виникають, частота і детальність виконання окремих операцій по управлінню ризиком можуть варіюватися у широких межах. Для підвищення ролі цього процесу директивою МО США введена нова фаза у проведенні типової програми фаза формування програми із зниження ризику. Успішна реалізація цієї фрази визначається стратегію придбання, проведенням заходів зниження ризику, адекватністю прототипів майбутнього виробу OBT, а також достатністю і достовірністю даних, що надаються підрядником. Загальні методи аналізу і управління ризиками, що використовуються у ході виконання програм придбання МО США, варіюються від простих методів складання і аналізу переліку критичних елементів програми (risk Watchlist) до реалізованих на обчислювальних засобах мережевих моделей програм (program Networks Analyzing)

За способами реагування на події ризику, інструкції і настанови для керівників програм придбання МО США виділяють п'ять основних аспектів:

- прийняття ризику (risk Assumption) - ризик i розвиток подій, що пов'язані $з$ ним, ретельно відслідковуються;

- ухилення від ризику (risk Avoidance) - для недопущення прояву небажаних наслідків реалізації випадків ризику у плани робіт вносяться відповідні зміни;

- контролю ризику (risk Control) - це спосіб боротьби з небажаним наслідком не до, а після прояву випадку ризику;

- передача ризику (risk Transfer) - передбачає реалізацію механізмів, що передбачають участь іншої сторони у компенсації втрат від випадків ризику або повну передачу цих втрат іншій стороні (страхова і контрактна політика);

- комбінація вищевказаних способів - найбільш ефективний варіант реагування.

Одним 3 найбільш ефективних підходів до зниження ризику американські фахівців вважають укладення контрактних угод, при яких наслідки випадків ризику розподіляються порівну між замовником і підрядником.

При виборі типажу контракту з точки зору ефективності управління ризиком рекомендується також враховувати наступні аспекти програми:

- ступінь визначеності майбутніх робіт;

- види і складність продукції, що створюється;

- тривалість виконання робіт;

- рівень конкуренції;

- ступінь важливості робіт.

Таким чином, оцінювання і управління ризиком є обов'язковим атрибутом системи придбання OBТ у США і інших розвинутих країнах світу.
У процедурі оцінювання широко використовуються експертні імовірнісні методи. При цьому оцінюється імовірність прояву небажаної події i масштабу отриманих наслідків його прояву. Управління ризиком здійснюється як завчасно, так і при прояві небажаної події. Використання методів оцінювання управління ризиком дозволяе досягати високих результатів реалізації проектів по створенню ОВТ в умовах невизначеності функціонування ринкової економіки. Більшість 3 перелічених аспектів і елементів практично відсутні у вітчизняній практиці програмного плануванням ДОЗ, хоч у наукових працях з розвитку економічного менеджменту цим питанням приділяється значна увага [11-15].

Це обумовлює необхідність використання у вітчизняній практиці воєнно-економічного обгрунтування ДОЗ досвіду провідних країн світу і подальшого розвитку (систематизації) методів оцінювання і управління ризиками при реалізації ДЦПР з урахуванням національних особливостей їх практичного втілення на усіх стадіях ЖЦ ОВТ [16-19]. При цьому необхідно враховувати те, що повного доступу до досвіду інших країни у цьому питанні отримати неможливо, тому розвиток національної науки у цій сфері є актуальними науковим завданням.

Мета статті - подати у систематизованому вигляді найбільш важливі аспекти оцінювання ризиків і управління ними у системі ДОЗ, з урахуванням накопиченого досвіду провідних країн світу у цій області діяльності і відпрацювання рекомендацій із зменшення рівня ризиків не реалізації ДЦПР.

\section{Виклад основного матеріалу}

Система ДОЗ - це організована сукупність взаємопов'язаних і взаємно узгоджених та залежних елементів і суб'єктів держави, що знаходяться у відношеннях і зв'язках один з одним, і утворюють певну цілісність, єдність загально-економічних і правових принципів, ієрархічний порядок формування, розміщення, фінансування і використання поставок продукції для державних потреб з підтримання необхідного рівня обороноздатності і боєздатності держави.

У загальному випадку ризик у системі дОЗ можливо описати як імовірність неотримання запланованого результату, або як величину відхилення отриманого результату від фактичного, або одночасно обох. Управління ризиком у системні ДОЗ має дві взаємопов'язаних складових: технологія управління, тобто сам процес управління, і організація управління. Управляти таким складним об'єктом, як ризик ДОЗ, неможливо без системного підходу.

Ризик виконання будь-якого заходу, що включений до ДОЗ, може буде поданий як можливість прояву небажаної події (можливість дострокового припинення виконання заходів унаслідок виникнен- 
ня обставин, що заважають його подальшому проведенню, або не отримання заданих (запланованих) результатів після завершення заходів). У загальному випадку управління ризиками у ДОЗ можуть бути представлені сукупністю організаційно-економічних заходів, що спрямовані на систематичне виявлення, аналіз, оцінювання, випередження і контроль подій випадкового і непередбачуваного характеру по запобіганню втратам інтересів держави і невиконання контрактів у межах ДОЗ. Найбільш розповсюдженими є методи уникнення від ризику. Оцінювання ризиків і управління ними має бути безперервним процесом, що охоплює проведення комплексу заходів, що спрямовані на виявлення, аналіз, усунення або зниження ризику до прийнятного рівня як у окремих областях (наприклад, фінансування робіт, термінів їх виконання, реалізації технічних рішень, забезпечення виробничої технологічності й інші), так і виконання програми у цілому [8]. Для об'єктивного оцінювання реалізації (не реалізації) заходів системи ДОЗ мають бути сформовані відповідні правила прийнятності для замовника результату виконання заходів, що враховують його специфіку.

Для науково-дослідної роботи (НДР) прийнятним результатом може бути створення наукової продукції у плановому періоді часу, що відповідає меті досліджень і містить обгрунтовані результати вирішення усіх задач, що поставлені у тактикотехнічному завданні (ТТЗ) на НДР. Для дослідноконструкторської роботи (ДКР) прийнятним результатом може бути завершена і прийнята розробка зразка ОВТ за запланований період часу із ТTХ не нижче визначених у ТТЗ на ДКР. Для виробництва (ремонту) зразків ОВТ прийнятним результатом може бути придбання МО виготовлених (відремонтованих) на підприємствах ОПК зразків ОВТ із заданими ТTХ у відповідності з запланованою динамікою їх закупки по роках планового періоду. При цьому прийнятність для замовника результату має бути ув'язана з факторами ризику. До основних причин виникнення невизначеності і ризику реалізації програмних заходів у системі ДОЗ при плануванні можуть бути віднесені:

- недостатні знання точного обліку перспективного зразку ОВТ, реалізації кінцевих значень ТТХ конструктивно-компонувальних рішень, матеріалів, технології, які будуть використані для його створення;

- неточність економіко-математичних моделей, що використовуються для прогнозування вартості і часу заходів;

- неповнота і неточність інформації про умови, у яких будуть реалізовуватись заходи ЖЦ перспективного зразка ОВТ;

- навмисне укриття (дезінформація) імовірним противником даних про ТТХ ОВТ, що розробляються ним.
Ризик нерезультативної реалізації заходів ДОЗ $\epsilon$ по суті інтегральним видом ризику, що характеризує у цілому дії усіх можливих факторів ризику на рівні, що розглядається. Для недопущення суттєвої розбіжності між реальною і програмною траєкторіями реалізації заходів у системі ДОЗ і зниження розміру розбіжностей доцільно сформувати стратегію управління ризиками. Загострення проблеми, що пов'язана з необхідністю підвищення якості планування і реалізації ДОЗ, потребує оперативного оцінювання ризиків у цій області, формування управлінських рішень на основі єдиної бази даних і проведення багатопараметричного аналізу виконання заходів і програм у системі ДОЗ. Це обумовлює необхідність автоматизації процесів управління ризиками, що потребує використання сучасних інформаційних технологій і відповідного апаратнопрограмного забезпечення [9-10]. Тому для автоматизації процесу інформаційно-аналітичної підтримки планування управління ризиками необхідна відповідна концептуальна модель, що відображає процедури аналізу ризиків у ході підготовки стратегічних і оперативних рішень та дозволяє оцінювати зміни рівня ризику, або фактори ризику, дії яких стануть більш імовірними або суттєвим. За результатами такого аналізу завчасно можуть бути розроблені заходи усунення або послаблення негативних впливів прояву факторів ризику. У системі виконання ДОЗ може виявлятись значна кількість різнорідних факторів ризику (табл. 1), отже може застосовуватись ряд методів і методик оцінювання ризиків. Важливою групою є фінансово-технологічна група ризиків, що виникають у системі ДОЗ у сфері ОПК в цілому. 3 урахуванням схожості складу фінансовотехнологічних ризиків на різних етапах обгрунтування, формування і реалізації ДОЗ у сфері ОПК до основних концептуальних напрямків побудови методологічного апарату оцінювання ризиків на цих етапах можуть бути віднесені:

- використання методичного апарату раннього виявлення ризиків і прогнозування можливих наслідків подій, що відповідають фінансово-технологічним ризикам;

- застосування для оцінювання ризиків методичного підходу, що зорієнтований на використання єдиних класифікаторів (табл. 1) елементарних факторів ризику на усіх етапах обгрунтування, формування і реалізації ДОЗ та проектів у їх складі і на усіх організаційних рівнях;

- використання стандартних і спеціалізованих методів і методик для проведення аналізу і оцінювання ризиків без жорсткого закріплення правил використання окремих методів при реалізації гнучкості цієї системи, а також можливості врахування особливостей, спрямованості і критерійної бази управління ризиками на різних ієрархічних рівнях. 
Приклад класифікації ризиків ДОЗ у сфері ОПК

\begin{tabular}{|c|c|c|c|c|c|}
\hline \multirow{2}{*}{$\begin{array}{c}\text { Рівень } \\
\text { управління }\end{array}$} & \multirow{2}{*}{$\begin{array}{c}\text { Види } \\
\text { ризиків }\end{array}$} & \multirow{2}{*}{$\begin{array}{c}\text { Назва } \\
\text { ризиків }\end{array}$} & \multicolumn{3}{|c|}{ Етап виконання ДОЗ } \\
\hline & & & $\begin{array}{c}\text { Форму- } \\
\text { вання }\end{array}$ & $\begin{array}{l}\text { Розмі- } \\
\text { щення }\end{array}$ & Реалізація \\
\hline \multirow{9}{*}{$\begin{array}{l}\text { Оборонно- } \\
\text { промислова } \\
\text { політика }\end{array}$} & \multirow{3}{*}{$\begin{array}{l}\text { Фінансово- } \\
\text { економічні }\end{array}$} & Структурні зміни ОПК & + & + & + \\
\hline & & 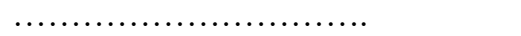 & & & \\
\hline & & $\begin{array}{l}\text { Зниження рівня бюджетного } \\
\text { фінансування }\end{array}$ & + & + & + \\
\hline & \multirow[t]{3}{*}{$\begin{array}{l}\text { Науково- } \\
\text { технічні }\end{array}$} & $\begin{array}{l}\text { Низький рівень конкурентоздат- } \\
\text { ності науково-технічної продук- } \\
\text { ції }\end{array}$ & + & + & + \\
\hline & & & & & \\
\hline & & $\begin{array}{l}\text { Відставання рівня ТТХ від світо- } \\
\text { вих аналогів }\end{array}$ & + & & + \\
\hline & \multirow{3}{*}{$\begin{array}{l}\text { Виробничо- } \\
\text { технологічні }\end{array}$} & Застарілість виробничої бази & + & + & + \\
\hline & & Застарілість елементної бази & + & + & + \\
\hline & & $\begin{array}{l}\text { Відсутність кооперації підпри- } \\
\text { ємств }\end{array}$ & + & + & + \\
\hline \multirow[t]{9}{*}{$\begin{array}{l}\text { Державний } \\
\text { замовник }\end{array}$} & \multirow[t]{3}{*}{$\begin{array}{l}\text { Фінансово- } \\
\text { економічні }\end{array}$} & $\begin{array}{l}\text { Зниження рівня бюджетного } \\
\text { фінансування }\end{array}$ & + & + & + \\
\hline & & $\begin{array}{lll}\text { Порушення правил розміщення } \\
\text { замовлення }\end{array}$ & & + & \\
\hline & & $\begin{array}{l}\text { Порушення правил розрахунків } \\
\text { по поставкам }\end{array}$ & & & + \\
\hline & \multirow[t]{3}{*}{$\begin{array}{l}\text { Науково- } \\
\text { технічні }\end{array}$} & $\begin{array}{l}\text { Неточність економіко- } \\
\text { математичних моделей }\end{array}$ & + & & + \\
\hline & & $\begin{array}{l}\text { Неповнота та неточність інфор- } \\
\text { мації про умови реалізації захо- } \\
\text { дів }\end{array}$ & & & + \\
\hline & & Дублювання робіт & + & + & \\
\hline & \multirow[t]{3}{*}{$\begin{array}{l}\text { Виробничо- } \\
\text { технологічні }\end{array}$} & $\begin{array}{ll}\text { Застарілість } & \text { виробничо- } \\
\text { технологічної бази } & \\
\end{array}$ & & + & + \\
\hline & & (n.w. & & & \\
\hline & & $\begin{array}{l}\text { Відсутність (втрата) технологіч- } \\
\text { ної бази у галузі }\end{array}$ & & + & + \\
\hline \multirow[t]{10}{*}{ Підприємство } & \multirow[t]{3}{*}{$\begin{array}{l}\text { Фінансово- } \\
\text { економічні }\end{array}$} & $\begin{array}{l}\text { Перевищення фактичних витрат } \\
\text { на запланованими }\end{array}$ & & + & + \\
\hline & & 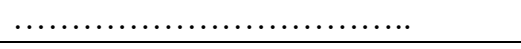 & & & \\
\hline & & Здороження продукції & & & + \\
\hline & \multirow[t]{3}{*}{$\begin{array}{l}\text { Науково- } \\
\text { технічні }\end{array}$} & $\begin{array}{lll}\text { Невиконання ТTХ до зразків } \\
\text { ОВТ }\end{array}$ & & & + \\
\hline & & Невиконання ТТЗ до ДКР & & & + \\
\hline & & $\begin{array}{l}\text { Припинення робіт } 3 \text { науково- } \\
\text { технічних причин }\end{array}$ & & & + \\
\hline & \multirow[t]{4}{*}{$\begin{array}{l}\text { Виробничо- } \\
\text { технологічні }\end{array}$} & $\begin{array}{l}\text { Відсутність (втрата) технологіч- } \\
\text { ної бази }\end{array}$ & & & + \\
\hline & & $\begin{array}{l}\text { Відсутність (втрата) персоналу у } \\
\text { потрібній чисельності із потріб- } \\
\text { ною кваліфікацією }\end{array}$ & & & + \\
\hline & & $\ldots \ldots \ldots \ldots \ldots \ldots \ldots \ldots \ldots \ldots \ldots \ldots$ & & & \\
\hline & & $\begin{array}{l}\text { Непостачання на виробництво } \\
\text { зразка ОВТ }\end{array}$ & & & + \\
\hline
\end{tabular}


У складі методичного апарату оцінювання фінансово-технологічних ризиків ДОЗ у сфері ОПК можуть бути виділені експертні, статистичні і спеціальні групи методів і методик.

Усі ризики слід оцінювати з урахуванням імо- вірності їх виникнення та потенційних наслідків не виконання заходів ДОЗ і програм.

Схема функціональної моделі оцінювання фінансово-технологічних ризиків у системі ДОЗ для управління ними, представлена на рис. 2.

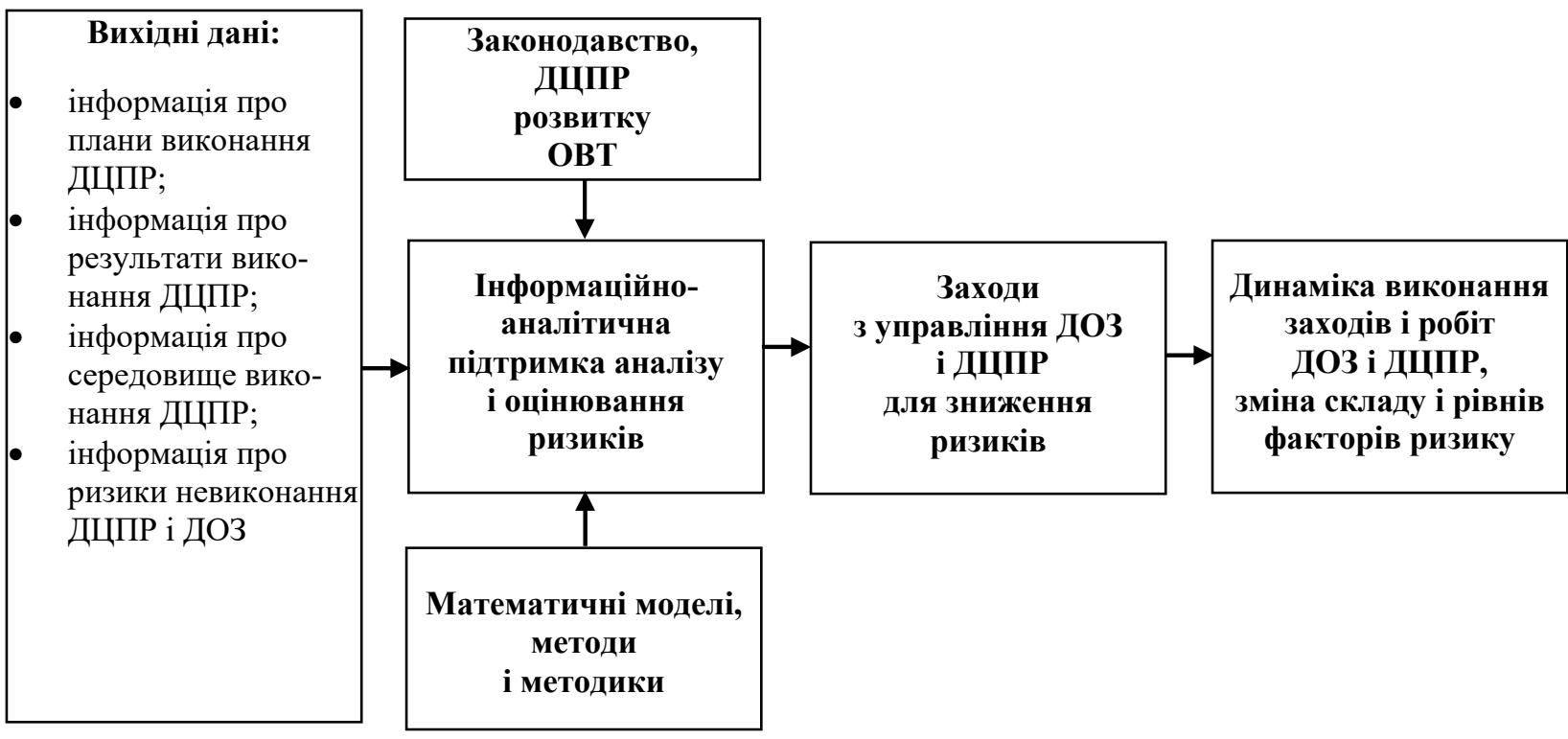

Рис. 2. Схема функціональної моделі оцінювання фінансово-технологічних ризиків ДОЗ і управління ризиками

Процес обробки ризиків має включати ідентифікацію і оцінювання різних варіантів розгляду ризиків, а також розробку і виконання планів менеджменту ризиків. Для потенційних загроз і можливостей спочатку слід визначити можливість їх обробки відомими методами або необхідність розробки нового (спеціального) методичного апарату і процедур менеджменту. Обробка ризиків має включати аналіз необхідних заходів, що сприяють мінімізації ризиків.

До можливих стратегій обробки ризиків можуть бути віднесені: ухилення від ризику; локалізація ризику; зниження ризику; компенсація або прийняття ризику.

На усіх стадіях процесу обробки ризику мають бути зафіксовані документально: висунуті припущення, розроблені методи, визначені джерела даних, результати аналізу причини прийнятих рішень.

Складність врахування динаміки складу важко передбачуваних змін умов діяльності при формуванні i реалізації ДЦПР i ДОЗ фінансовоекономічного, організаційного, науково-технічного, виробничо-технологічного й іншого характеру викликає необхідність використання процесного підходу до управління ризиками і обумовлює актуальність автоматизації процесів управління ними із застосуванням сучасних інформаційних технологій (рис. 3).

При розробці й реалізації економічно обгрунтованих для суб'єктів ДОЗ практичних рекомендацій і заходів, що спрямовані на зменшення рівня ризику, доцільно керуватися сукупністю таких положень і установок, як:

- необхідність врахування діапазону часових меж ризику;

- визначення зони економічної стійкості ДОЗ;

- використання ієрархічної моделі управління ризиками у системі ДОЗ;

- визначення основних груп і підгруп ресурсів, що необхідні для забезпечення нормального функціонування системи ДОЗ;

- визначення очікуваних або бажаних результатів, які мають бути отримані.

Прагнення використовувати теорію і методи управління ризиками у системі ДОЗ достатньо нове явище у вітчизняній практиці. Однак від активності їх втілення у значному ступені залежить ефективність формування і реалізації ДОЗ, а від цього, у свою чергу, реалізуємось планів вдосконалення системи озброєння ЗС держави, в умовах прояву значної кількості негативних факторів, які призводять до виникнення ризикових ситуації. 


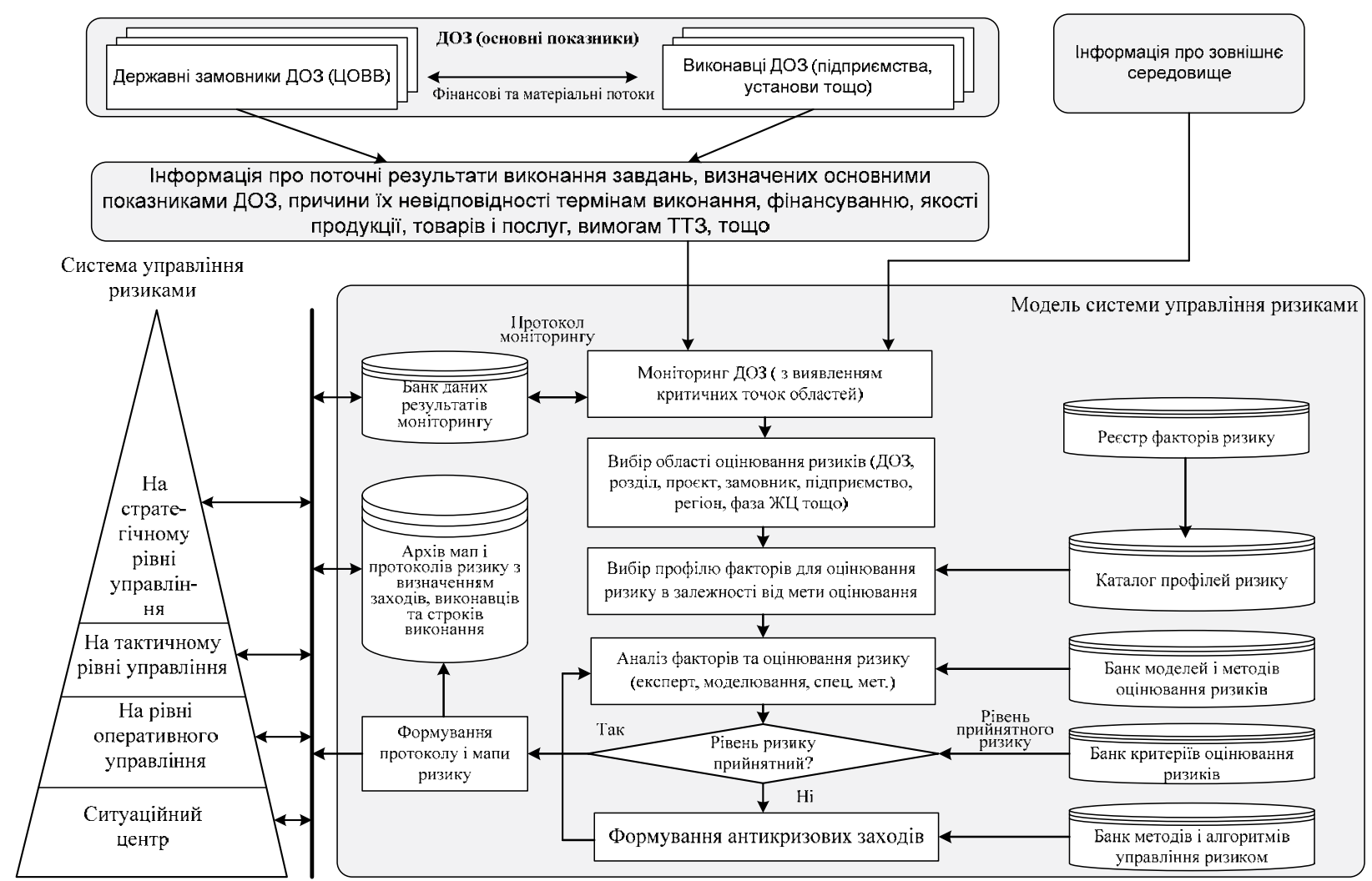

Рис. 3. Інформаційно-функціональна модель системи управління ризиками державних цільових програм та ДОЗ

При формуванні проекту ДОЗ і наступному його затвердженні суттєве значне мають результати оцінювання стану науково-технічного і виробничотехнологічного потенціалів підприємств ОПК, що розглядаються у якості можливих виконавців різних проектів на стадіях ЖЦ зразків ОВТ, які мають складати основу системи озброєння ЗС держави.

Комплексне оцінювання підприємств (визначення їх рейтингу) має спиратись на використання процедур обробки даних, що отримується у процесі аналізу виробничо-технологічних, інноваційних, мобілізаційних і інших можливостей ОПК, а також очікуваних проявів факторів ризику.

\section{Висновки}

Вирішальною умовою підвищення ефективності функціонування системи ДОЗ $є$ наявність науково-методичних основ управління ризиками, які мають містити загальноекономічні, управлінські і організаційні аспекти і структурно складатись з базових елементів: теоретичних установок, принципів i понятійного апарату, механізмів (процедур, порядку, методичного апарату) оцінки ефективності (методів і критеріїв) функціонування системи ДОЗ.

Особливістю методів оцінювання факторів ризику у системи ДОЗ є необхідність визначення рівня втрат від їх впливу, у першу чергу, у показниках вартості і ефективності.
У першому випадку у якості характеристики втрат доцільно використовувати обсяг коштів, який може бути втрачений безрезультатно 3 причини зриву робіт ДОЗ внаслідок наявності невизначеності фінансово-економічного, науково-технічного і виробничо-технологічного характеру. Такий показник і відповідні методи його розрахунку доцільно використовувати на мікрорівні (на рівні конкретних робіт).

У другому випадку у якості характеристики втрат може використовуватись ступінь недовиконання задач, що вирішуються системою озброєння 3С, внаслідок тих або інших причин. Його доцільно використовувати на макрорівні (при обгрунтуванні плану в цілому).

Використання методів оцінювання ризиків i управління ними дозволило провідним країнам світу досягти значних результатів реалізації проектів у створенні зразків ОВТ у цілому в умовах невизначеності. Цей накопичений досвід доцільно узагальнити і враховувати у вітчизняній практиці воєнноекономічного обгрунтування і реалізації ДОЗ з вибором адекватних об'єктивних умов моделі управління ризиками та умовами функціонування фінансового контролю за ефективним (по цільовому призначенню) використанням виділених ресурсів.

Необхідно створення дієвого бережливого механізму господарювання ОПК держави в умовах прояву різних факторів ризику, у тому числі групи 
факторів фінансово-технологічних ризиків. Доцільно ввести в апарат управління МО спеціалістів, що володіють системною методологією оцінювання ризиків і управління ними, наділених повноваженнями по втіленню у практику проведення оборонно- промислової політики держави і виконання відповідних практичних контрольних функцій, безпосередньо пов'язаних з діяльністю суб'єктів, які приймають участь у процесах (заходах і роботах) з формування і реалізації державних оборонних замовлень.

\section{Список літератури}

1. Системно-концептуальные основы военно-научных исследований и решения прикладных военно-технических задач: монография в 3-х книгах. Кн. 2 / Б.А. Демидов, С.Н. Остапенко, М.И. Луханин, и др.; под ред. Б.А. Демидова. Тверь, 2014. - 688 с.

2. Методические основы системных исследований и решения проблем технического оснащения вооруженных сил государства: монография в двух книгах. Книга 2 / Б.А. Демидов, О.П. Коростылев, С.Н. Остапенко, Д.А. Гриб и др.; под ред. Б.А. Демидова и О.П. Коростылева. - К.: ИД““Стилос”, 2016. - 640 с.

3. Буренок В.М. Методология обоснования перспектив развития средств вооруженной борьбы общего назначения / В.М. Буренок, А.В. Погребняк, А.М. Скотников. - М.: Машиностроение, 2010. - 368 с.

4. Теоретические основы автоматизации процессов управления программами в сфере оборонно-промышленного комплекса с учетом рисков их решений / Под ред. В.Н. Минаева, Н.В. Латышева. - Тверь: ООО “Экслибрис”, 2012. $280 \mathrm{c}$.

5. Демидов Б.А. Методический подход к оцениванию риска модернизации образцов вооружения и военной техники в условиях нестахостической неопределённости / Б.А. Демидов, М.В. Науменко, О.А. Хмелевская // Радіоелектронні і компьютерні системи. - 2009. -№ 3(37). - С.127-135.

6. Ушаков Ю.А. Система управления государственными закупками в обеспечении национальной безопасности США / Ю.А. Ушаков, Д.Ю. Ципулев. -М.: Ком Книга, 2005. - 48 с.

7. Высокие технологии в США: Опыт министерства обороны и других ведомств / Д.О. Рогозин, И.А. Шеремет, С.В. Гарбук, А.М. Губинский. - М.: изд-во Московского университета, 2013. - 384 с.

8. Лавринов Г.А. Управление рисками в системе государственного оборонного заказа: монография / Г.А. Лавринов, М.Н. Козин. - Саратов: Наука, 2010. - 255 с.

9. Оценка научно-технической и производственно-технологической реализуемости проектов на стадиях жизненного цикла сложных технических систем: монография / Д.А. Вареник, В.В. Витчинка, М.В. Волков и др.; под ред. С.Н. Остапенко. -Тверь: изд-во ЗНП АО “Отделение ПВЭ и Ф”, 2015. - 275 с.

10. Методы и модели ситуационного анализа при управлении развитием сложных технических систем: монография / И.Н. Глушков, Н.В. Латышев, В.Н. Минаев, С.Н. Остапенко. - Тверь, 2012. - 624 с.

11. Дамодаран А. Стратегический риск-менеджмент. Принципы и методики / А. Дамодаран. - М.: Вильямс, 2010. $496 \mathrm{c}$.

12. Ніценко В.С. Управління ризиками на підприємствах агропродовольчої сфери [Електронний ресурс] / В.С. Ніценко, С.В. Руденко // Актуальні проблеми інноваційної економіки. - 2017. - № 3. - С. 12-21. - Режим доступу: http://nbuv.gov.ua/UJRN/apie_2017_3_4.

13. Мостенська, Т.Л. Ризик-менеджмент як інструмент управління господарським ризиком підприємства / Т.Л. Мостенська, Н.С. Скопенко // Вісник Запорізького національного університету. Економічні науки. - 2010. - № 3. - С. $72-79$.

14. Бартон Т.Л. Риск-менеджмент. Практика ведущих компаний / Т.Л. Бартон, У.Г. Шенкир, П.Л. Уокер. - М.: Вильямс, 2008. -208 с.

15. Посохов I. Аналіз досліджень зарубіжних наукових шкіл ризик-менеджменту / I. Посохов // Маркетинг і менеджмент інновацій. -2013. - № 4. - С. 164-172. - Режим доступу: http://mmi.fem.sumdu.edu.ua/.

16. STANAG 4728 System Life Cycle Management.

17. AAP-48 NATO System Life Cycle Processes.

18. AAP-20 NATO Programme Management Framework (NATO Life Cycle Model).

19. STANREC 4755 Reference Documents On Life Cycle Costs.

\section{References}

1.Demydov, B.A., Ostapenko, S.N. and Lukhanyn, M.Y. (2014), "Systemno-kontseptualnye osnovy voenno-nauchnykh yssledovanyi y reshenyia prykladnykh voenno-tekhnycheskykh zadach: monohrafyia $v 3-k h$ knyhakh. Kn. 2” [System-conceptual foundations of military research and the solution of applied military-technical problems: a monograph in 3 books. Book 2], Tver, $688 \mathrm{p}$.

2. Demydov, B.A., Korostylev, O.P., Ostapenko, S.N. and Hryb, D.A. (2016), "Metodycheskye osnovy systemnykh yssledovanyi y reshenyia problem tekhnycheskoho osnashchenyia vooruzhennykh syl hosudarstva" [Methodical basis of systematic research and solution of problems of technical equipment of the armed forces of the state], Stylos, Kyiv, $640 \mathrm{p}$.

3. Burenok, V.M., Pohrebniak, A.V. and Skotnykov, A.M. (2010), "Metodolohyia obosnovanyia perspektyv razvytyia sredstv vooruzhennoi borby obshcheho naznachenyia" [Methodology for substantiating the prospects for the development of general-purpose military weapons], Mashynostroenye, Moscow, 368 p.

4. Mynaev, V.N. and Latyshev, N.V. (2012), "Teoretycheskye osnovy avtomatyzatsyy protsessov upravlenyia prohrammamy v sfere oboronno-promyshlennoho kompleksa s uchetom ryskov ykh reshenyi" [Theoretical Foundations of Automation of 
Program Management Processes in the Field of the Military-Industrial Complex Considering the Risks of Their Solutions], OOO "Ekslybrys", Tver, 280 p.

5. Demydov, B.A., Naumenko, M.V. and Khmelevskaia, O.A. (2009), "Metodycheskyi podkhod k otsenyvanyiu ryska modernyzatsyy obraztsov vooruzhenyia y voennoi tekhnyky v uslovyiakh nestakhostycheskoi neopredelënnosty" [Methodological approach to assessing the risk of upgrading weapons and military equipment in the context of non-stochastic uncertainty], Radioelectronic and Computer Systems, No. 3(37), pp. 127-135.

6. Ushakov, Yu.A. and Tsypulev, D.Yu. (2005), "Systema upravlenyia hosudarstvennymy zakupkamy $v$ obespechenyy natsyonalnoi bezopasnosty SShA" [US Public Procurement Management System], Kom Knyha, Moscow, 48 p.

7. Rohozyn, D.O., Sheremet, Y.A., Harbuk, S.V. and Hubynskyi, A.M. (2013), "Vysokye tekhnolohyy v SShA: Opyt mynysterstva oborony y druhykh vedomstv" [High Tech in the United States: Experience from the Department of Defense and Other Agencies], Moscow University publishing house, Moscow, 384 p.

8. Lavrynov, H.A. and Kozyn, M.N. (2010), "Upravlenye ryskamy v systeme hosudarstvennoho oboronnoho zakaza: monohrafyia" [Risk Management in the State Defense Order System: monograph], Nauka, Saratov, 255 p.

9. Varenyk, D.A., Vytchynka, V.V. and Volkov, M.V. (2015), "Otsenka nauchno-tekhnycheskoi y proyzvodstvennotekhnolohycheskoi realyzuemosty proektov na stadyiakh zhyznennoho tsykla slozhnykh tekhnycheskykh system: monohrafyia" [Assessment of scientific, technical and industrial-technological feasibility of projects at the stages of the life cycle of complex technical systems: monograph], ZNP AO “Otdelenye PVE y F”, Tver, 275 p.

10. Hlushkov, Y.N., Latyshev, N.V., Mynaev, V.N. and Ostapenko, S.N. (2012), "Metody i modely sytuatsyonnoho analyza pry upravlenyy razvytyem slozhnykh tekhnycheskykh system: monohrafyia" [Methods and models of situational analysis in managing the development of complex technical systems: monograph], Tver, $624 \mathrm{p}$.

11. Damodaran, A. (2010), "Stratehycheskyi rysk-menedzhment. Pryntsypy y metodyky" [Strategic Risk Taking: A Framework for Risk Manage], Villiams, Moscow, 496 p.

12. Nitsenko, V.S. and Rudenko, S.V. (2017), "Upravlinnia ryzykamy na pidpryiemstvakh ahroprodovolchoi sfery" [Management of riziks at food and agricultural enterprises], Aktualni problemy innovatsiinoi ekonomiky, No. 3, pp. 12-21, available at: www. nbuv.gov.ua/UJRN/apie 201734.

13. Mostenska, T.L. and Skopenko, N.S. (2010), "Ryzyk-menedzhment yak instrument upravlinnia hospodarskym ryzykom pidpryiemstva" [Risk management as a tool for managing an enterprise's economic risk], Visnyk Zaporizkoho natsionalnoho universytetu. Ekonomichni nauky, No. 3, pp. 72-79.

14. Barton, T.L., Shenkyr, U.H. and Uoker, P.L. (2008), "Rysk-menedzhment. Praktyka vedushchykh kompanyi" [Risk management. The practice of leading companies], Vyliams, Moscow, $208 \mathrm{p}$.

15. Posokhov, I. (2013), "Analiz doslidzhen zarubizhnykh naukovykh shkil ryzyk-menedzhmentu" [Analysis of research of foreign scientific schools of risk management], Marketynh i menedzhment innovatsii, No. 4, pp. 164-172, available at: www.mmi.fem.sumdu.edu.ua

16. NATO (2015), NATO - STANAG 4728 System Life Cycle Management, 6 p

17. NATO (2013), NATO - AAP-48 NATO System Life Cycle Stages and Processes, 68 p.

18. NATO (1989), NATO PROGRAMME MANAGEMENT FRAMEWORK (NATO Life Cycle Model), 124 p.

19. NATO (2015), STANREC 4755: 2015 Reference Documents on Life Cycle Costs.

Відомості про авторів:

\section{Турінський Олександр Васильович}

кандидат технічних наук

начальник Харківського національного

університету Повітряних Сил ім. І. Кожедуба,

Харків, Україна

https://orcid.org/0000-0001-6888-6045

\section{Демідов Борис Олексійович}

доктор технічних наук професор провідний науковий співробітник Харківського національного університету

Повітряних Сил ім. І. Кожедуба,

Харків, Україна

https://orcid.org/0000-0003-1728-6925

\section{Гриб Дмитро Анатолійович}

кандидат військових наук доцент головний науковий співробітник

Харківського національного університету

Повітряних Сил ім. І. Кожедуба,

Харків, Україна

https://orcid.org/0000-0001-8478-978X

\section{Information about the authors:}

\section{Oleksandr Turinskyi}

Candidate of Technical Sciences

Chief of Ivan Kozhedub Kharkiv

National Air Force University,

Kharkiv, Ukraine

https://orcid.org/0000-0001-6888-6045

\section{Boris Demidov}

Doctor of Technical Sciences

Professor

Lead Research of Ivan Kozhedub

Kharkiv National Air Force University, Kharkiv, Ukraine

https://orcid.org/0000-0003-1728-6925

\author{
Dmytro Gryb \\ Candidate of Military Sciences \\ Associate Professor \\ Chief Research of Ivan Kozhedub \\ Kharkiv National Air Force University, \\ Kharkiv, Ukraine \\ https://orcid.org/0000-0001-8478-978X
}




\section{Хмелевська Ольга Олександрівна}

кандидат технічних наук

старший науковий співробітник

провідний науковий співробітник

Харківського національного університету

Повітряних Сил ім. І. Кожедуба,

Харків, Україна

https://orcid.org/0000-0001-9018-5552

\section{Olga Khmelevska}

Candidate of Technical Sciences

Senior Research

Lead Research

of Ivan Kozhedub

Kharkiv National Air Force University,

Kharkiv, Ukraine

https://orcid.org/0000-0001-9018-5552

\title{
НАУЧНО-МЕТОДОЛОГИЧЕСКИЕ АСПЕКТЫ УПРАВЛЕНИЯ РИСКАМИ В СИСТЕМЕ ГОСУДАРСТВЕННОГО ОБОРОННОГО ЗАКАЗА
}

\author{
А.В. Туринский, Б.А. Демидов, Д.А. Гриб, О.А. Хмелевская
}

В статье рассматриваются актуальные аспекты, связанные с процедурами формирования и реализации государственных оборонных заказов в условиях проявления различных факторов риска. Основное внилание сосредоточено на научно-методическом подходе к оченке уровня ожидаемых рисков и управления этими рисками. Отмечается, что использование при формировании и реализачии государственного оборонного заказа соответствующих адекватных методов, моделей и методик будет способствовать уменьшению уровня риска и повышению результативности выполнения задач и мероприятий государственного оборонного заказа. Доказана иелесообразность учета в отечественной практике накопленного положительного опыта ведущих стран мира по уменьщению рисков невыполнения научных и других перспективных (инновационных) проектов создания образиов вооружения и военной техники, которые должны составлять основу системы вооружения вооруженных сил государства. Под риском в статье понимается мера неспособности достижения иеели программы в рамках запланированной стоимости, сроков работ и технических требований, что наделяет риски составляющими вероятности недосягаемости конкретной цели программы и последствий недосягаемости данной цели. По опыту МО США выделяются аспекты принятия риска, уклонения от риска, контроля риска, передачи риска и комбинации вышеуказанных способов реагирования на событие риска. Выделяется наиболее важный метод оценки факторов риска в системе государственного оборонного заказа, ориентированный на установление величины потерь экономического характера. Приводится актуальность проблемы управления рисками в прочессе выполнения мероприятий государственного оборонного заказа и государственных целевых программ развития вооружения и военной техники в условиях увеличения неопределенности и все большего расширения масштабов проявления факторов риска. Выделена необходимость создания действенного бережливого механизма хозяйствования обороннопромышленного комплекса государства в условиях проявления различных факторов риска на всем периоде жизненного иикла системы вооружения вооруженных сил.

Ключевые слова: государственный оборонный заказ, факторы рисков в системе государственного оборонного заказа, методы оценки уровня проявления факторов риска, методы управления рисками.

\section{SCIENTIFIC AND METHODOLOGICAL ASPECTS OF RISK MANAGEMENT IN THE PUBLIC DEFENSE ORDER SYSTEM}

\section{O. Turinskyi, B. Demidov, D. Gryb, O. Khmelevska}

The article deals with topical aspects related to the procedures of formation and implementation of state defense orders in the conditions of manifestation of various risk factors. The main focus is on a scientific and methodological approach to assessing the level of expected risks and managing those risks. It is noted that the use of appropriate adequate methods, models and techniques in the formation and implementation of the state defense order will help reduce the level of risk and increase the efficiency of the performance of the tasks and measures of the state defense order. It is proved that it is expedient to take into account in the domestic practice the accumulated positive experience of the leading countries of the world on reducing the risks of non-implementation of scientific and other promising (innovative) projects of creating models of weapons and military equipment, which should form the basis of the system of the armed forces of the state. The risk in the article refers to the measure of the inability to achieve the program objective within the planned cost, service life and technical requirements, which gives the risk of the components of the probability of unreachability of a specific goal of the program and the consequences of its unavailability. In the experience of the US Department of Defense, there are aspects of risk taking, risk avoidance, risk control, risk transfer and a combination of the above methods for responding to a risky event. The most important method of estimating risk factors in the system of state defense order is highlighted, which is oriented to establishing the magnitude of economic losses. The urgency of the problem of risk management in the process of implementation of measures of the state defense order and state targeted programs of the development of weapons and military equipment in the conditions of increasing uncertainty and increasing scale of manifestation of risk factors. The necessity to create an effective economic mechanism for managing the defense-industrial complex of the state under the conditions of manifestation of various risk factors during the life cycle of the armed forces systems is emphasized.

Keywords: state defense order, risk factors in the system of state defense order, methods of assessing the level of manifestation of risk factors, methods of risk management. 